\title{
Potentialities and limitations of agricultural use in soils of semi-arid region of the state of Bahia
}

\author{
ALEXSANDRA F. DE QUEIROZ ${ }^{1}$, ALESSANDRA M. SALVIANO ${ }^{2}$, TONY J.F. DA CUNHA ${ }^{2}$, NELCI \\ OLSZEVSKI ${ }^{3}$, VALDOMIRO S. DE SOUZA JÚNIOR ${ }^{4}$ and MANOEL B. DE OLIVEIRA NETO ${ }^{5}$ \\ ${ }^{1}$ Instituto Federal de Educação Ciência e Tecnologia do Rio Grande do Norte (IFRN), Campus \\ Caicó, Rodovia RN-288, s/n, Nova Caicó, 59300-000 Caicó, RN, Brazil \\ ${ }^{2}$ Empresa Brasileira de Pesquisa Agropecuária, Centro de Pesquisa Agropecuária do Trópico Semi \\ Árido, Rodovia BR-428, Km 152m, s/n, Zona Rural, 56302-970 Petrolina, PE, Brazil \\ ${ }^{3}$ Universidade Federal do Vale do São Francisco/UNIVASF, Colegiado de Engenharia Agrícola e Ambiental, \\ Avenida Antônio Carlos Magalhães, 510, Santo Antônio, 48902-300 Juazeiro, BA, Brazil \\ ${ }^{4}$ Universidade Federal Rural de Pernambuco/UFRPE, Departamento de Agronomia, Área de Solos, \\ Rua Dom Manoel de Medeiros, s/n, Dois Irmãos, 52171-900 Recife, PE, Brazil \\ ${ }^{5}$ Empresa Brasileira de Pesquisa Agropecuária, Embrapa Solos, UEP Recife, R. \\ Antônio Falcão, 402, Boa Viagem, 51020-240 Recife, PE, Brazil
}

Manuscript received on January 9, 2018; accepted for publication on February 13, 2018

\begin{abstract}
The objective of this study was to evaluate the potentialities and limitations of the agricultural use of representative classes of semi-arid regions of the state of Bahia, based on the pedological and evaluation of their soil characteristics. Five areas were selected where trenches were opened to collect samples for the analyses: Eutric Haplustept which presents vulnerability to physical and chemical degradation due to poor drainage with risks of erosion, waterlogging, salinization and compaction but having good natural fertility; Abrupt Kandiustalf with high vulnerability to physical degradation due to the presence of gravel and pebbles which may limit the development of deep rooting plants and mechanization but also with good natural fertility; Typic quartzipsaments and Typic Eutrustalf with no limitations related to drainage as low risk of compaction but featuring limitation of low moisture-holding capacity and nutrients; and Arenic Haplustulf wose characteristics are high vulnerability to degradation due to the drainage limitation related to the Btx horizon cementing in addition to low natural fertility and therefore is not recommended to agricultural use. However, in general, they feature no serious impediments for agricultural use. The amounts of OM is low in all soils but the use of management systems aiming at their accumulation and maintenance in appropriate levels will contribute to the CEC increase as well as to improve the chemical and physical properties.
\end{abstract}

Key words: sustainable, soil quality, physical attributes, use limitations, soil degradation.

Correspondence to: Alessandra Montiero Salviano

E-mail: alessandra.salviano@embrapa.br 


\section{INTRODUCTION}

The natural variability of the types of soil in a landscape is a result of complex interactions between factors and formation processes which defines its physical, chemical and mineralogical properties, as well as its agricultural potential. The interaction between these properties, the plants and the edaphic organisms affects the soil's functioning and its role in the functioning of the ecosystems, that is, in the construction and maintenance of its biodiversity (Vezzani 2015), influencing its capacity to provide ecosystem services.

Therefore, the soil has a fundamental role in the construction of this condition, because it is through it that occurs the plant structure's development, and, because of that, the supply of energy and material to the living beings of the terrestrial food chains (Vezzani 2015). Because of that, having the knowledge of the types of soil through pedological studies is crucial to the comprehension of the physical, chemical and biological processes which will allow the implementation of sustainable agroecosystems. The results of these studies are even more relevant when made in areas in which its soils present low resilience and high susceptibility to physical, chemical and biological degradation when submitted to anthropic actions, being recognized as fragile soils (Castro and Hernani 2015). Within the characteristics, there are sandy texture, low organic matter content, low stability of the aggregates, or, still, its location in the landscape (slope and susceptible to water erosion reliefs) (Adem and Tisdall 1984, Gerard 1986, Reeleder et al. 2006). Such soils can be generally found in semi-arid regions; they constitute around $15 \%$ of the global land area and $62 \%$ of the Northeast region of Brazil $\left(970.000 \mathrm{~km}^{2}\right)$. In the last decades, there has been widespread interest in environmental trends and problems of poverty and economic development in semi-arid areas because their crop and livestock production is the primary economic activity and a key supporting ecosystem service in these regions, as defined by the Millenium Ecosystem Asessment (2005).

Even though there are information around the soils of this region (Jacomine et al. 1976, Cunha et al. 2008, Cunha et al. 2010, Dantas et al. 1998, Santos and Ribeiro 2000, Santos et al. 2012), it is important to make studies in a more detailed scale, in areas with intense agricultural activities which are in regions with environmental fragility and that include water bodies of social and economic relevance. In this context, there is the Environmetal Preservation Area Sobradinho's lake, located in the state of Bahia, created in 2006, with an estimated area of 1.000.000 ha and many environmental conflicts, such as deforestation, Fires, and the use of agricultural practices in the flood quota of the lake. The agricultural production, based mostly in fruticulture and olericulture, uses the areas discovered after, the depletion of the lake, in the system of "ebbing", using irrigation, fertilization (mainly chemical), and chemical pesticides to pests and diseases control.

Thereby, considering the importance of the soil quality to the maintenance of the ecosystem services in the Environmetal Preservation Area Sobradinho's lake, such as food supply, climate regulation, nutrient cycling, and the maintenance of the quantity and quality of the water, this study aimed tto evaluate the potentialities and limitations of the agricultural use of representative classes of semi-arid regions of the state of Bahia, based on the pedological and evaluation of their soil characteristics.

\section{MATERIALS AND METHODS}

\section{PHYSICAL ENVIRONMENT CHARACTERIZATION}

The study area is located between the parallels $9^{\circ} 9^{\prime} 43^{\prime \prime}$ south latitude and the meridian $40^{\circ} 58^{\prime}$ $15^{\prime \prime}$ west longitude, in the Brazilian semi-arid inserted into São Francisco Structural Province. 
The area consists, mostly, of Precambrian rocks (granites, migmatites, schists and quartzites). It takes part of the caribbeans group, represented by rocks with high degree of metamorphism, having as main component the gray biotite-gneiss, which it associates amphibolites, mica schists and quartzites. The quartzites stand out in the landscape of flattened surface forming ridges and saws. The regional average altitude is around 400 to 500 m (Brasil 1973). The area's natural vegetation is tropical dryforest, but currently dominated by secondary vegetation at different successional stages, agricultural cropsand, mainly, pasture. The climate (Koppen) is classified as BSwh', corresponding to a semi-arid region with average annual temperature of $26.0^{\circ} \mathrm{C}$ and minimum and maximum of $21.2^{\circ} \mathrm{C}$ and $32.7^{\circ} \mathrm{C}$, respectively. The average annual rainfall is $481.7 \mathrm{~mm}$, with the highest rainfall observed from February to April. The dry season occurs from June to November and the air average relative humidity is $67 \%$.

\section{PROFILES LOCATION, DESCRIPTION AND SOILS SAMPLING}

The area selection was held with the participation of technical assistance agencies and local producers associations in rural properties with agricultural use on the Sobradinho's Lake shore and with an adjacent area of caatinga biome secondary vegetation.
Selected profiles were morphologically described and sampled according to (Santos et al. 2005). Soils were classified, according to U.S. Soil Taxonomy (Soil Survey Staff 2014) nearest equivalent: Eutric Haplustept (P01), Abrupt Kandiustalf (P02), Typic Quartzipsaments (P03), Arenic Haplustulf(P04) and Typic Eutrustalf (P05) (Table I). Soil samples for chemical and physical analysis were collected in surface and subsurface with a diagnosis of the horizons of each profile studied.

Physical analyses included: grain size with the sand particle size fraction according to the granulometric classification of the United States Department of Agriculture (USDA); Clay dispersed in water; particle density; soil density by measuring method and total porosity classification (Donagema et al. 2011). The macroporosity and microporosity were estimated through the mathematical model proposed by Stolf et al. (2011). The characteristic curve of soil water retention in voltages of $6 ; 10$; $30 ; 60 ; 100$ and $1500 \mathrm{kPa}$ was held by centrifugal method (Silva and Azevedo 2002) and the water retention values were adjusted by van Genuchten (1980).

The chemical analysis carried out according to Donagema et al. (2011) included: $\mathrm{pH}$ in water (1:2.5), phosphorus $(\mathrm{P})$, calcium $(\mathrm{Ca})$, magnesium $(\mathrm{Mg}), \operatorname{sodium}(\mathrm{Na})$, potassium $(\mathrm{K})$, aluminum $(\mathrm{Al})$, organic carbon (OC) (determined by the wet method with potassium dichromate), copper $(\mathrm{Cu})$, iron $(\mathrm{Fe})$,

TABLE I

Profiles' location, soil classification and physical environment data.

\begin{tabular}{|c|c|c|c|c|}
\hline Profile & Geographical Coordinates & $\begin{array}{c}\text { Landscape } \\
\text { Situation }\end{array}$ & Drainage & Source Material \\
\hline P01 & $0277831 \mathrm{~S}$ and $8977046 \mathrm{~W}$ & Flat & $\begin{array}{l}\text { Moderate to } \\
\text { imperfectly drained }\end{array}$ & Gneiss/mica schists alteration \\
\hline $\mathrm{P} 02$ & $0273599 \mathrm{~S}$ and $8989071 \mathrm{~W}$ & Flat & Well drained & Gneiss alteration product \\
\hline P03 & $0194314 \mathrm{~S}$ and $8935964 \mathrm{~W}$ & Flat & Heavily drained & Change in the sediment of the tertiary \\
\hline P04 & $0208653 \mathrm{~S}$ and $8935453 \mathrm{~W}$ & Flat & Imperfectly drained & Change in the sediment of the tertiary \\
\hline P05 & $0211311 \mathrm{~S}$ and $8936607 \mathrm{~W}$ & Flat & Well drained & Change in the sediment of the tertiary \\
\hline
\end{tabular}


manganese $(\mathrm{Mn})$ and zinc $(\mathrm{Zn})$ contents; potential acidity $(\mathrm{H}+\mathrm{Al})$ and electrical conductivity (EC) in the folder extract of saturation. From the results obtained were calculated: sum of bases (SB); cation exchange capacity (CEC); bases saturation (BS) and the exchange sodium percentage (ESP).

\section{RESULTS AND DISCUSSION}

MORPHOLOGICAL, PHYSICAL AND WATER ATTRIBUTES

The Eutric Haplustept presents horizons sequence A-BA-Bi1-Bi2-BC, depth greater than $170 \mathrm{~cm}$ and flat and clear transitions between horizons. The color varied along the profile, from hue $10 \mathrm{YR}$ in the horizons $\mathrm{A}$ and $\mathrm{BA}$ to $2.5 \mathrm{YR}$ in the horizons $\mathrm{Bi} 1, \mathrm{Bi} 2$ and $\mathrm{BC}$. There is presence of mottled (Black 10 YR 2/1) from the BA horizon, due to the imperfect drainage and the occurrence of small patches of bluish-grey coloration $(10 \mathrm{~B} / 6)$ from the Bi2 horizon. According to Ribeiro et al. (2012), the presence of mottled generally indicates restricted drainage conditions, being observed in soils that exhibit low permeability horizon and, or, those which are located in landscape positions that favor the oscillation of the water table level. In addition, the roots present horizontal growth indicating impediment to elongation and it can be associated with the excess moisture in some periods of the year and the very hard consistency of the underlying horizons (Table II). This may be related the distribution of particle size fractions in the horizons (Table III).

The sand proportions decrease in depth, ranging from $471 \mathrm{~g} \mathrm{~kg}^{-1}$ in the A horizon up to $403 \mathrm{~g} \mathrm{~kg}^{-1}$ in the BC. With the predominance of fine and very fine fractions in all horizons. This implying in density values ranging from 1.28 a $1.38 \mathrm{~kg} \mathrm{dm}^{-3}$, considered adequate for the textural class (Reichert et al. 2016; Reichert et al. 2014; Reichert et al. 2003). There is gradual increase of clay in depth, with proportions ranging from 300 $\mathrm{g} \mathrm{kg}^{-1}$ in the A horizon to the $398 \mathrm{~g} \mathrm{~kg}^{-1}$ in the $\mathrm{Bi} 2$. According to Oliveira (2005) the slight difference in the proportion of this textural fraction along the profile is one of the characteristics of this soil. In addition, in BA and Bil horizons, little unedged gravels from the parental rocks were observed. The structure is moderate, small and medium in subangular blocks in the A horizon; weak, medium in angular blocks in BA; massive in the Bil and Bi2 horizons; weak, small and medium in angular blocks in BC. Considering the consistency over its profile (Table II), it is recommended that before mechanization, a great point of moisture must be set in order to minimize the impact of machinery and vehicles on the different dynamic properties and on the development of cultures. According to Mota et al. (2008), the mechanical operations carried out in great tracks of soil moisture, do not damage the soil structure and they require the minimum power of the agricultural engines, increasing its useful life, besides enabling cost reduction with fuel and the equipment maintenance. In addition, the high proportion of micropores in the total porosity composition ( 77 to $89 \%$ ) of that soil, when compared to the values typically found in soils of same texture (Cunha et al. 2011), contributed to greater retention of water content in different points of water characteristic curve voltage (Figure 1), compared to other profiles. Water management in this soil must consider such characteristics, in order to avoid problems of waterlogging. The horizons $\mathrm{BC}, \mathrm{A}$ and $\mathrm{BA}$, in descending order, have a higher water retention capacity (Figure 1). The $\mathrm{Bi} 2$ horizon presents the greatest difference from the others in terms of water retention in the same tension. The decrease in water content retained in greater tensions can be seen in all horizons.

The Abrupt Kandiustalf presents the sequence of horizons A-BA-Bt1-Bt2-Bt3 and depth exceeding $100 \mathrm{~cm}$ with flat and gradual transition in $\mathrm{BA}$ and $\mathrm{Bt} 1$, and flat and clear in all other horizons. The color presents variation along the profile: hue 
TABLE II

Morphological attributes of five representative soils classes.

\begin{tabular}{|c|c|c|c|c|c|c|c|}
\hline \multirow{2}{*}{$\begin{array}{l}\text { Hor } \\
\text { Hor }\end{array}$} & \multirow{2}{*}{$\begin{array}{l}\text { Depth } \\
\text { Cm }\end{array}$} & \multirow{2}{*}{$\begin{array}{l}\text { Moist Color }^{(1)} \\
\text { Munsell }\end{array}$} & \multirow{2}{*}{ Structure $^{(2)}$} & \multicolumn{3}{|c|}{ Consistency } & \multirow[t]{3}{*}{ Transition } \\
\hline & & & & Dry $^{(3)}$ & Moist & Wet $^{(4)}$ & \\
\hline \multicolumn{7}{|c|}{ P1: Eutric Haplustept } & \\
\hline $\mathbf{A}$ & $0-15$ & $\begin{array}{l}\text { 10YR 4/4 br. } \\
\text { yello. dark }\end{array}$ & mod..sma. and med.. bl. sub. & $\begin{array}{l}\text { sli. } \\
\text { hard }\end{array}$ & Firm & $\begin{array}{l}\text { plas. and } \\
\text { sti. }\end{array}$ & Flat and clear \\
\hline BA & $15-35$ & $\begin{array}{l}\text { 10YR 5/4br. } \\
\text { yello. }\end{array}$ & wea.. med.. bl. ang. & $\begin{array}{l}\text { Very } \\
\text { hard }\end{array}$ & Firm & $\begin{array}{l}\text { plas. and } \\
\text { sti. }\end{array}$ & Flat and clear \\
\hline Bi1 & $35-80$ & $2.5 \mathrm{Y} 5 / 4 \mathrm{br}$. red. & Massive & $\begin{array}{l}\text { Very } \\
\text { hard }\end{array}$ & $\begin{array}{l}\text { Very } \\
\text { firm }\end{array}$ & $\begin{array}{l}\text { plas. and } \\
\text { sti. }\end{array}$ & Flat and clear \\
\hline $\mathrm{Bi} 2$ & $80-130$ & $2.5 \mathrm{Y} 5 / 4 \mathrm{br}$. red. & Massive & $\begin{array}{l}\text { Very } \\
\text { hard }\end{array}$ & $\begin{array}{l}\text { Very } \\
\text { firm }\end{array}$ & $\begin{array}{l}\text { plas. and } \\
\text { sti. }\end{array}$ & Flat and clear \\
\hline BC & $\begin{array}{l}130- \\
170^{+}\end{array}$ & $2.5 Y 5 / 6 \mathrm{red}$ & wea..sma. and med.. bl. ang. & smooth & Friable & $\begin{array}{l}\text { plas. and } \\
\text { sti. }\end{array}$ & - \\
\hline \multicolumn{8}{|c|}{ P2: Abrupt Kandiustalf } \\
\hline $\mathbf{A}$ & $0-10$ & $\begin{array}{l}\text { 10YR 4/4 br. } \\
\text { yello. dar. }\end{array}$ & $\begin{array}{l}\text { wea.. sma. and med.. bl. } \\
\text { ang. }\end{array}$ & $\begin{array}{l}\text { sli. } \\
\text { hard }\end{array}$ & Friable & $\begin{array}{l}\text { nplas. } \\
\text { and nsti. }\end{array}$ & Flat and clear \\
\hline BA & $10-33$ & $\begin{array}{l}\text { 7.5YR } 4 / 6 \text { br. } \\
\text { strong }\end{array}$ & $\begin{array}{c}\text { wea.. sma. and med.. bl. } \\
\text { ang. }\end{array}$ & Hard & Friable & $\begin{array}{l}\text { sli. plas. } \\
\text { and sti. }\end{array}$ & $\begin{array}{l}\text { Flat and } \\
\text { gradual }\end{array}$ \\
\hline Bt1 & $33-55$ & $\begin{array}{l}\text { 5YR 5/6 red- } \\
\text { yello. }\end{array}$ & - & - & - & $\begin{array}{l}\text { plas. and } \\
\text { nsti. }\end{array}$ & Flat and clear \\
\hline Bt2 & $55-85$ & $\begin{array}{l}\text { 5YR 4/6 red- } \\
\text { yello. }\end{array}$ & - & - & - & $\begin{array}{l}\text { nplas. } \\
\text { and nsti. }\end{array}$ & Flat and clear \\
\hline Bt3 & $85-100^{+}$ & - & - & - & - & - & - \\
\hline \multicolumn{8}{|c|}{ P3: Typic quartzipsaments } \\
\hline $\mathbf{A}$ & $0-15$ & $\begin{array}{l}\text { 10YR 5/6 br. } \\
\text { yello. }\end{array}$ & Common clean sand grains & Smooth & Loose & $\begin{array}{l}\text { nplas. } \\
\text { and nsti. }\end{array}$ & Flat and clear \\
\hline C1 & $15-55$ & $\begin{array}{l}10 \mathrm{YR} 5 / 6 \text { br. } \\
\text { yello. }\end{array}$ & Common clean sand grains & Smooth & Loose & $\begin{array}{l}\text { nplas. } \\
\text { and nsti. }\end{array}$ & $\begin{array}{l}\text { Flat and } \\
\text { diffuse }\end{array}$ \\
\hline $\mathrm{C2}$ & $55-110$ & $\begin{array}{l}\text { 10YR 5/8 br. } \\
\text { yello. }\end{array}$ & Common clean sand grains & Smooth & Loose & $\begin{array}{l}\text { nplas. } \\
\text { and nsti. }\end{array}$ & $\begin{array}{l}\text { Flat and } \\
\text { diffuse }\end{array}$ \\
\hline C3 & $110-160$ & $\begin{array}{l}\text { 10YR 5/8 br. } \\
\text { yello. } \\
10 Y R / 8\end{array}$ & Common clean sand grains & Smooth & Loose & $\begin{array}{l}\text { nplas. } \\
\text { and nsti. }\end{array}$ & $\begin{array}{l}\text { Flat and } \\
\text { diffuse }\end{array}$ \\
\hline $\mathrm{C4}$ & $\begin{array}{l}160- \\
200^{+}\end{array}$ & $\begin{array}{c}\text { brownish- } \\
\text { yellow }\end{array}$ & Common clean sand grains & Smooth & Loose & $\begin{array}{l}\text { nplas. } \\
\text { and nsti. }\end{array}$ & - \\
\hline \multicolumn{8}{|c|}{ P4: Arenic Haplustulf } \\
\hline A & $0-20$ & $\begin{array}{l}\text { 10YR } 4 / 4 \text { br. } \\
\text { yello. dark }\end{array}$ & Common clean sand grains & Loose & Loose & $\begin{array}{c}\text { nplas. } \\
\text { and nsti. }\end{array}$ & Flat and clear \\
\hline E1 & $20-55$ & $10 Y \mathrm{R} 5 / 6 \mathrm{br}$ & Common clean sand grains & Loose & Loose & $\begin{array}{l}\text { nplas. } \\
\text { and nsti. }\end{array}$ & $\begin{array}{l}\text { Flat and } \\
\text { diffuse }\end{array}$ \\
\hline $\mathbf{E 2}$ & $55-110$ & 10YR 5/8 br. & Common clean sand grains & Loose & Loose & $\begin{array}{l}\text { nplas. } \\
\text { and nsti. }\end{array}$ & $\begin{array}{c}\text { Flat and } \\
\text { abrupt }\end{array}$ \\
\hline Btx & $110-140$ & $\begin{array}{l}10 Y \mathrm{R} 6 / 3 \mathrm{br} . \\
\text { light gray. }\end{array}$ & wea.. med. and lar.. bl. ang. & Hard & Firm & $\begin{array}{l}\text { plas. and } \\
\text { sli.sti. }\end{array}$ & - \\
\hline \multicolumn{8}{|c|}{ P5: Typic Eutrustalf } \\
\hline A & $0-20$ & $\begin{array}{l}\text { 10YR 5/4 br. } \\
\text { yello. }\end{array}$ & wea.. sma.. bl. ang. & $\begin{array}{l}\text { sli. } \\
\text { Hard }\end{array}$ & Friable & $\begin{array}{l}\text { nplas. } \\
\text { and nsti. }\end{array}$ & Flat and clear \\
\hline Bt1 & $20-40$ & $\begin{array}{l}\text { 7.5YR 5/6 br. } \\
\text { strong }\end{array}$ & $\begin{array}{c}\text { wea.. sma. and med.. bl. } \\
\text { ang. }\end{array}$ & $\begin{array}{l}\text { sli. } \\
\text { Hard }\end{array}$ & $\begin{array}{l}\text { Very } \\
\text { friable }\end{array}$ & $\begin{array}{l}\text { sli. plas. } \\
\text { and nsti. }\end{array}$ & $\begin{array}{l}\text { Flat and } \\
\text { diffuse }\end{array}$ \\
\hline Bt2 & $40-75$ & $\begin{array}{l}\text { 7.5YR } 5 / 8 \text { br. } \\
\text { strong }\end{array}$ & $\begin{array}{l}\text { wea.. sma. and med.. bl. } \\
\text { ang. and sub }\end{array}$ & Smooth & $\begin{array}{l}\text { Very } \\
\text { friable }\end{array}$ & $\begin{array}{l}\text { sli. plas. } \\
\text { and sli. } \\
\text { sti. }\end{array}$ & $\begin{array}{l}\text { Flat and } \\
\text { diffuse }\end{array}$ \\
\hline Bt3 & $75-100^{+}$ & $\begin{array}{l}\text { 7.5YR } 5 / 8 \text { br. } \\
\text { strong }\end{array}$ & $\begin{array}{l}\text { wea.. sma. and med.. bl. } \\
\text { ang. and sub. }\end{array}$ & Smooth & $\begin{array}{l}\text { Very } \\
\text { friable }\end{array}$ & $\begin{array}{l}\text { sli. plas. } \\
\text { and sli. } \\
\text { sti. }\end{array}$ & - \\
\hline
\end{tabular}

(1)br.: brown; yello.: yellowish; dark.: dark; red.: reddish; gray.: grayish; ${ }^{(2)}$ mod.: moderate; wea.: weak; sma.: small; med.: medium; lar.: large; bl.: blocks; ang.: angular; sub.: subangular. ${ }^{(3)}$ sli.: slightly; ${ }^{(4)}$ plas.: plastic; sti.: sticky; nplas.: nonplastic; nsti.: nonsticky; sli. plas.: slightly plastic; sli. sti.: slightly sticky. 


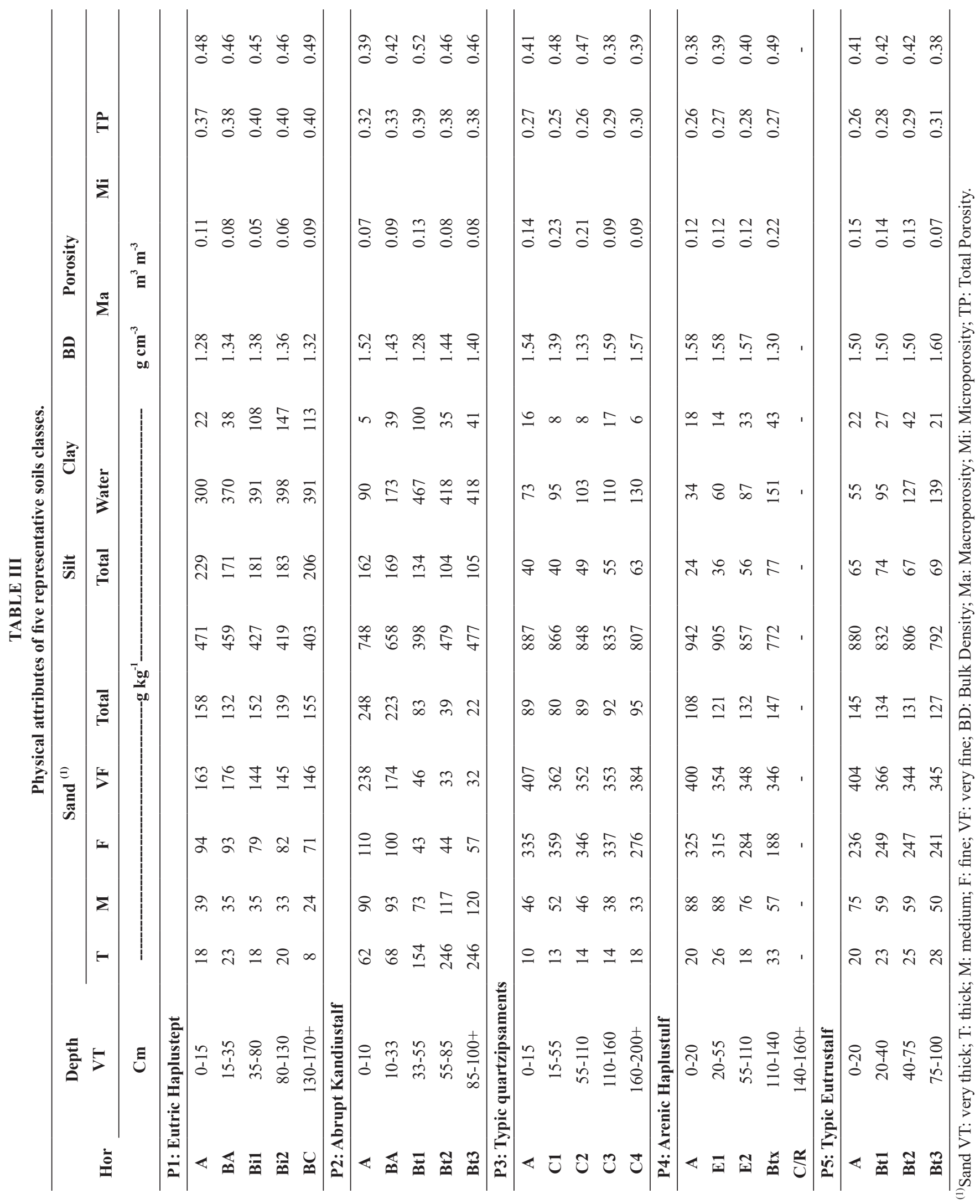


P1: Eutric Haplustept

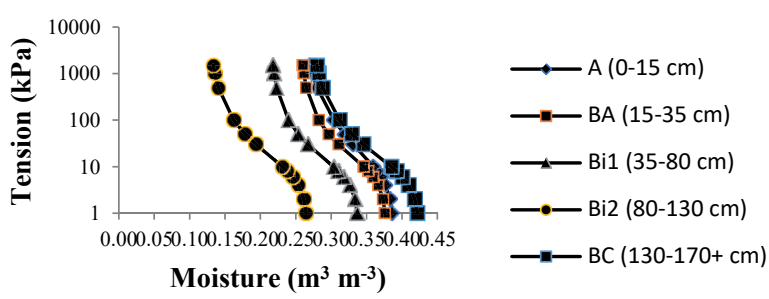

P2: Abrupt Kandiustalf

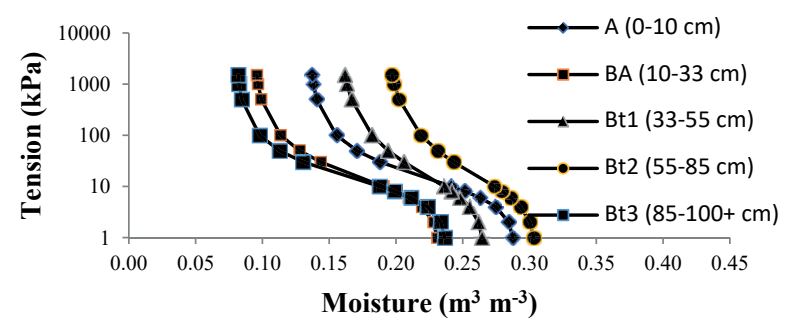

P3: Typic quartzipsaments

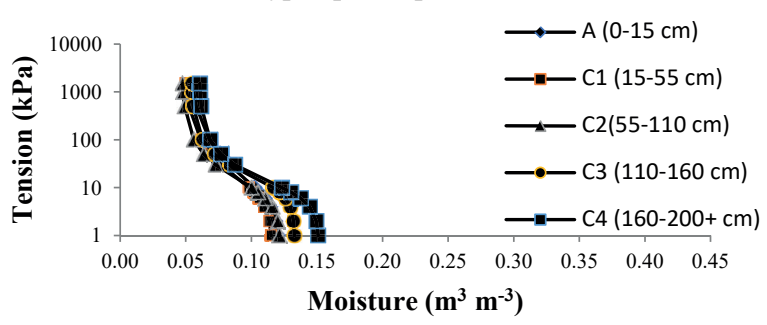

P4: Arenic Haplustulf

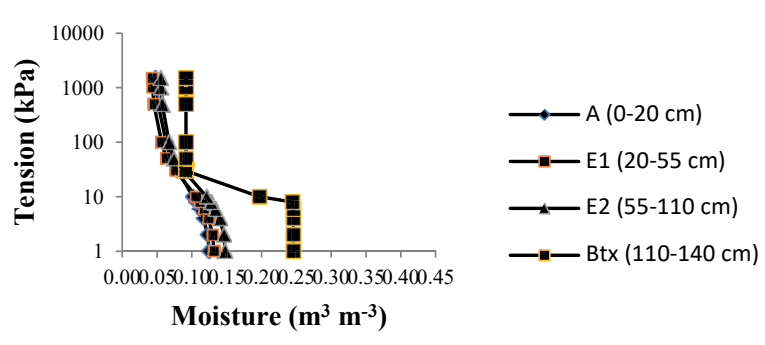

P5: Typic Eutrustalf
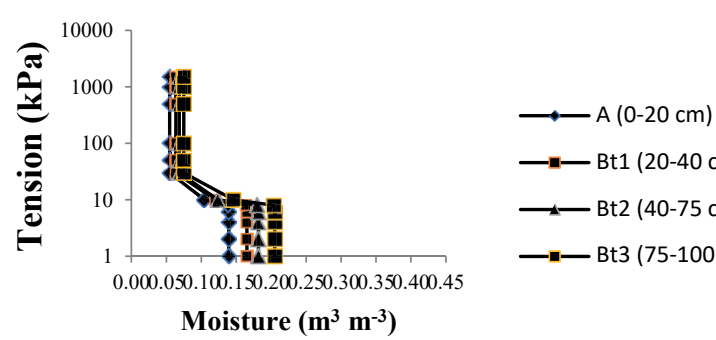

- $\mathrm{Bt} 1(20-40 \mathrm{~cm})$

- Bt2 $(40-75 \mathrm{~cm})$

-

Figure 1 - Water retention characteristic curve of soils.
10YR in the A horizon, 7.5YR in the BA and 5YR in the $\mathrm{Bt} 1$ and $\mathrm{Bt} 2$. There is presence of common medium and distinctive mottled, light olive brown $(2.5 \mathrm{Y} 5 / 3)$ in the Bt1 and abundant mottled, medium and distinctive, light olive brown (2.5Y 5/4). This indicating water table fluctuation, provided mainly by seasonality of the lake quota leading to the reduction of iron and formation of mottled in the deeper horizons. In addition, the presence of rare roots in $\mathrm{Bt} 1$ and $\mathrm{Bt} 2$ horizons confirm that with increasing depth, there is a greater impediment to the root system growth. The strong presence of gravels and pebbles from the Bt1 horizon coupled with the clay proportion increase from 90 and 173 $\mathrm{g} \mathrm{kg}^{-1}$ in the A and BA horizons, respectively, to $467 \mathrm{~g} \mathrm{~kg}^{-1}$ in Bt1 and $418 \mathrm{~g} \mathrm{~kg}^{-1}$ in Bt2 and Bt3 and wet plastic consistency and very sticky may justify the difficulty of the root system. However, as these characteristics combined with the increased density and high proportion of micropores in the total porosity composition (from 75 to $83 \%$ ) (Table III) appear from $55 \mathrm{~cm}$ deep, do not represent strong limitation for the oleraceas cultivation, species of greatest agricultural expression and exploiting the most superficial layer of the soil. It is highlighted that this increase of clay in the B horizon. Ultisol pedogenetic feature, can facilitate the occurrence of erosion processes in function of discontinuity in the water dynamics, despite the terrain is flat, i.e. ranging from 0 to $3 \%$ slope. In relation to water retention curves, the Abrupt Kandiustalf (Figure 1) has similar behavior to Eutric Haplustept in the outlined format, concerning differences in the water quantities retained between their horizons. However, in general, it is observed that the water content retained along the profile is less than the Eutric Haplustept content and upper than the other soils, whereas the same tension. The greater water retention, in $\mathrm{Bt} 1$ and $\mathrm{Bt} 2$ horizons, can be related to higher clay proportion and high proportion of micropores, as well as in Eutric Haplustept. While in the surface horizons, the proportions of fine 
sand and very fine sand may have influence on the behavior shown by the curves (Table III).

The Typic quartzipsaments presents sequence of horizons A-C1-C2-C3-C4 with depth greater than $200 \mathrm{~cm}$. flat and clear transition between the horizons $\mathrm{A}$ and $\mathrm{C} 1$ and. among others, flat and diffuse (Chart 2). The profile is uniform in relation to their color with 10YR hue in all horizons. The structure is common clean sand grains in all horizons and the consistency when dry, moist and wet are smooth, loose, nonplastic and nonsticky, respectively. This structural behavior can be associated with a little variation in particle size composition with a sand fraction predominance (variation from 807 to 887 $\mathrm{g} \mathrm{kg}^{-1}$ ) with greater representation of medium and fine fractions (Table III). despite the increase in the clay proportion in depth (from $73 \mathrm{~g} \mathrm{~kg}^{-1}$ in the A horizon to $130 \mathrm{~g} \mathrm{~kg}^{-1}$ in the $\mathrm{C} 4$ horizon). The textural composition implies higher density values (Table III). but below the critical value for sandy soils when it is above of $1.80 \mathrm{~kg} \mathrm{dm}^{-3}$ (Reichert et al. 2015; Reichert et al. 2014; Reichert et al. 2003). The greatest limitation of this soil is its low water retention capacity and, it is observed that the curves of all horizons are very similar and, virtually, overlap mainly in $\mathrm{C} 1$ and $\mathrm{C} 2$ horizons (Figure 1).

The sand texture implies high proportion of macropores in the TP (Table III), setting up easy drainage and. consequently, high leaching. However, the different size classes of the sand fraction are important in this capacity, suggesting that the predominance of medium and fine fractions may indicate greater water availability (Oliveira. 2005), compared to other soils with thicker slices. In general, it is important that the water management in this soil to avoid the waste of this resource, as well as the nutrients leaching. However, Faria et al. (2007) emphasize that with the technologies advancement, mainly on the water management and the nutrients application (fertirrigation), the Typic quartzipsaments, which also occupy a significant area in the region, have been successfully exploited by the fruit growers. Considering its morphological characteristics, it is possible to point out that there are not impediments to mechanization for not presenting stoniness, to be very deep and heavily drained to be inserted in a flat terrain.

The Arenic Haplustulf presents sequence of horizons A-E1-E2-Btx-C/R with depth up to $140 \mathrm{~cm}$, where the saprolite begins along with the consolidated rock layer. Transitions between horizons are: flat and clear from the A horizon to the E1; flat and diffuse from the E1 horizon to E2; and flat and abrupt from the E2 horizon to the Btx. The color did not show variation in hue, remaining in $10 \mathrm{YR}$, but with variation in the chroma and value. The presence of abundant, small, distinctive and red-yellowish mottled (5YR 5/8) in E1 and E2 horizons and common, Medium, prominent and red mottled (2.5YR 4/6) in the Btx horizon indicate restriction on this drainage soil, despite the very sandy texture in all horizons (Table III). However, sand fraction decreased in depth. ranging from $942 \mathrm{~g} \mathrm{~kg}^{-1}$ in the A horizon to $772 \mathrm{~g} \mathrm{~kg}^{-1}$ in the Btx, along with the predominance of the medium and the fine sand fractions and the increase of silt and clay proportion, implying in high proportion of micropores in the TP (from 55 to $70 \%$ ). The roots are common. medium and fine in $\mathrm{A}$ and $\mathrm{E} 1$ horizons, rare in the $\mathrm{E} 2$ horizon, pointing impediment to root development with the depth, although the soil bulk density is within the range considered adequate for the textural class (Reichert et al. 2003, 2014, 2015). The A, E1 and E2 horizons feature common clean sand grains and the Btx presents weak structure, medium-to-large, in angular blocks. In terms of consistency: dry, moist and wet, loose, nonplastic and nonsticky respectively, in A, E1 and E2 horizons. The Btx presents hard, firm, plastic and slightly sticky consistency. The use of the " $x$ " suffix in the Bt horizon indicates the presence of cementation, apparently reversible in this horizon, since this condition can be undone under damping. Cementing is an unfavorable characteristic to 
agricultural use, because it constitutes a barrier to the water percolation and roots growth (Ribeiro et al.. 2012), however, as in this soil is situated below $110 \mathrm{~cm}$, it does not cause problems. It is worth pointing out that this ground is situated in a flat terrain and it does not present stoniness, therefore it does not offer impediment to mechanization. Water retention curves in the A, E1 and E2 horizons (Figure 1) exhibit similar behavior to the Typic quartzipsaments, but it may be also justified by the particle size composition of these horizons. However, the Btx displays an atypical situation to present greater water retention than the other horizons in low tension, having a sharp decrease for higher tensions.

Probably due to the occurrence of an apparent reversible cementing in this horizon, since this hard consistency layer may be a deterrent to the soil retain higher water content in larger, as it occurs at low tensions. In binary texture soils, especially those with contrasting texture or abrupt textural change, the water behavior presents important variations along the profile, especially among the A, E and B horizons (Oliveira. 2005). Therefore, it is recommended to consider their physical and morphological characteristics for the suitable soil and water management, with a view to their very sandy texture, providing high water infiltration in the A, E1 and E2 horizons, and restriction on the drainage in the Btx horizon.

The Typic Eutrustalf presents sequence of horizons A-Bt1-Bt2-Bt3 with depth until $100 \mathrm{~cm}$ where it begins the occurrence of unedged pebbles and gravels. The transition is flat and clear from the A horizons to the Bt1, flat and diffuse among other horizons (Table II). The color varies in the hue from 10 YR in the A horizon to 7.5 YR in Bt1, Bt2 and $\mathrm{Bt} 3$. The mottled absence and roots distribution indicate that there is not limit to drainage nor physical impediment and it may be related to the very sandy texture (sand proportions over $792 \mathrm{~g}$ $\mathrm{kg}^{-1}$ ) and to the appropriate density, despite the high proportion of micropores in the total porosity composition (63 to $82 \%$ ) (Table III). The medium and fine sand fractions are prevalent and the silt and clay proportions are low. Oliveira (2005) points out that it is very common for the Ultisol present sandy or medium texture in the surface, and this could facilitate the soil preparation. Considering the fertility, it emphasizes that it is in the coarse fractions (silt and sand) that minerals able to provide, after intemperization, nutrients for plants (Resende et al.. 2002), since the predominant mineral is not quartz. Related to the clay fraction, there is a gradual increase from $55 \mathrm{~g} \mathrm{~kg}^{-1}$ to $139 \mathrm{~g}$ $\mathrm{kg}^{-1}$ in the A horizon to the Bt3. Thus, evaluating the morphological characteristics and the particle size fractions distribution along the profile, it is possible to point out that this soil offers good conditions for the management and mechanization for providing good drainage. it does not present stoniness up to $100 \mathrm{~cm}$ and low erosion susceptibility. The A horizon present weak structure type, small in angular blocks. The Bt1 is weak, small and medium in angular blocks and. in Bt2 and Bt3 horizons it is weak, small and medium in angular and subangular blocks. The dried consistency is slightly hard in the A and Bt1 horizons and smooth in the $\mathrm{Bt} 2$ and $\mathrm{Bt} 3$ horizons. When it is moist, it is friable in the A and Bt1 horizons and very friable in Bt2 and Bt3. The wet consistency is nonplastic and nonsticky in the A horizon, slightly plastic and nonsticky in Bt1 and slightly plastic and slightly sticky in Bt2 and Bt3 horizons. Water retention curves show a distinction between their horizons with regard to the water retention in low tensions (Figure 1). The water retention is greater in depth and it may be related to an increase in the clay proportion and a high proportion of fine and very fine sand fractions (Table III). At higher tensions, the curves almost overlap and they do not present significant differences between horizons. Lepsch (2011) reports that, besides the quantity, the clay quality has influence on the water amount a soil 
can retain. However, as this soil has low amount of clay. Probably, the predominance of the finer sand fractions helps to increase water retention capacity.

Considering the particle size, the water holding capacity and other physical and morphological attributes of studied soils, the adoption of soil management practices that contribute to the increase in the OM content is an important strategy for the sustainable management of agricultural systems in the region. Silva et al. (2007) proposed the production "in situ" of organic material for the chemical, physical and biological characteristics improvement of the soil via soil coverage, is a potential alternative management in São Francisco Valley region, not only by avoiding the direct impact of raindrops, but mainly, to reduce the evaporation rate and raise the soil OM contents.

\section{CHEMICAL ATTRIBUTES}

The Eutric Haplustept. in superficial horizons, presented $\mathrm{pH}$ value lower than the track considered suitable for most cultures, but with contents of $\mathrm{Ca}$ and $\mathrm{Mg}$ (Alvarez V. et al. 1999) reflecting in high sum of bases (SB). This may be associated with the high OM contents and high clay proportion, contributing to a good CEC. On horizon Bil occurs significant increase of all the attributes described above. This behavior may be associated with less leaching because higher clay proportion and higher proportion the micropores. Contents of exchangeable $\mathrm{Na}$, in the surface horizons, are low, resulting in low ESP. However, it has increased on horizon Bil, and it can be attentive at possible salinization process in conditions of restricted drainage. Therefore, the EC is low, not indicating excessive concentration of salts in this soil. The availability of $\mathrm{P}$ is low and decreased with depth. This behavior is considered typical of this element, in function of its low mobility, as well as the greater $\mathrm{OM}$ contents in the surface horizons. Silveira et al (2006) confirmed that in tropical soils the organic-P is the most important fraction in the soil. Regarding to the micronutrients levels, the soil shows good ability to supply the plants (Alvarez V. et al. 1999).

In the Abrupt Kandiustalf, the $\mathrm{pH}$ and $\mathrm{Ca}, \mathrm{Mg}$ and $\mathrm{K}$ contents are adequate for agricultural use (Alvarez et al. 1999) reflecting in high SB. It is important to be attentive to the $\mathrm{Na}$ content that, in the same way as the other elements, they have significant increase after $33 \mathrm{~cm}$ deep. This increase may be associated with higher clay proportion and microporosity, reducing free drainage and favoring their accumulation in the profile. Despite this, the EC and ESP are within the range considered normal for the plants development, and it is important to be attentive for excessive use of chemical fertilizers that can lead to salinization process. P levels are very low, requiring external source of this element according to the requirements of culture. Souza et al. (2010), Araújo et al. (2004) and Oliveira et al. (1998), also found low P contents in soils of region of semi-arid climate in Brazil. The micronutrients levels are high in all horizons, but lower than the levels found in Eutric Haplustept.

The Typic quartzipsaments presents $\mathrm{pH}$ is adequate for agricultural use (Table IV), but $\mathrm{P}, \mathrm{Ca}$, $\mathrm{Mg}$ and $\mathrm{K}$ contents, SB and CEC denote a soil with low fertility. The high proportion of the sand and, consequently, of the macropores (Table III), combined with low OM content, favor drainage and leaching process. Corrêa et al. (2009) observed low $\mathrm{P}$ tenors in sandy soils with native vegetation in the semi-arid, ranging from $7.4 \mathrm{mg} \mathrm{dm}^{-3}$ at $4.1 \mathrm{mg} \mathrm{dm}^{-}$ ${ }^{3,} 0$ to $60 \mathrm{~cm}$ deep, noting that higher levels in the areas under different agricultural uses are resulting from the external sources provision of this nutrient. The Na contents are low, resulting in lows EC and ESP, not limiting the agricultural use of this soil. The salts in excess, can compromise plant growth, besides affecting some soil physical properties such as hydraulic conductivity, infiltration and aeration (Freire and Freire 2007). The micronutrient tenors range from medium to low, following the 


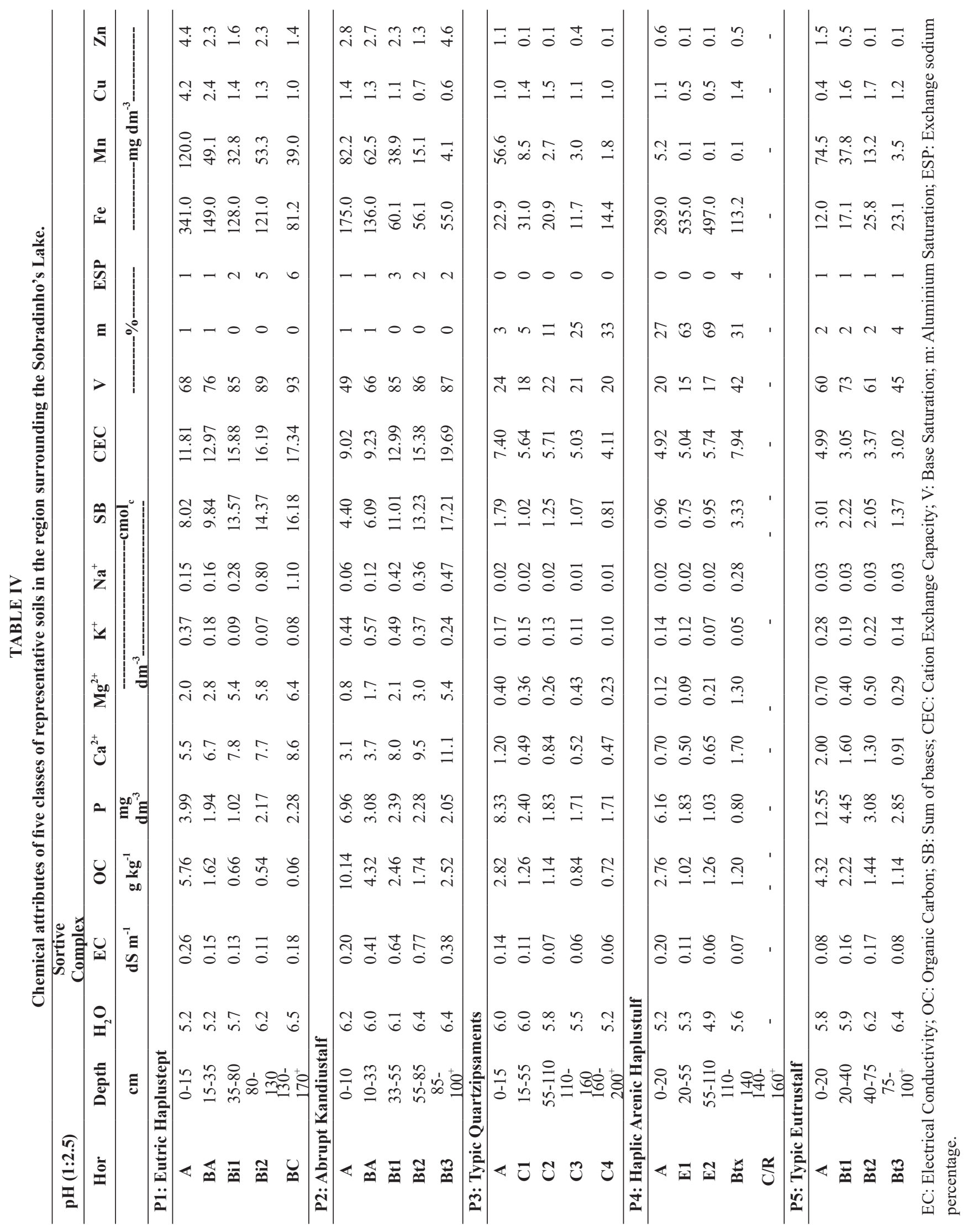


same trend of macronutrients due to low amount of granulometric particules with specific surface and load highs. Due to their low natural fertility, it becomes essential the proper management of fertilizer in order that the agricultural use is sustentable and the risks of the contamination be minimized.

The Arenic Haplustulf presents low natural fertility, represented by low sum of bases. CEC and $\mathrm{OC}$ contents. These characteristics, associated the extremely sandy texture, allows to classify it as a soil of high fragility. The low OC levels are characteristic of semi-arid region soils (Faria et al. 2007), since the physical and climatic conditions (low rainfall and high temperatures) do not provide adequate production of organic waste by the plants, combined with high decomposition rates. In these conditions, in order to have a CEC increase, it becomes of utmost importance the development of sustainable agricultural system, with management practices that contribute to the enhancement and maintenance of OM as green manure, Tillage, soil cover and crop rotation. The soil does not present problems of salinity, with low Na lcontents and low EC and ESP. The m saturation, mainly in subsurface horizons, presented higher values compared to the others, which it is not common to soils in semi-arid conditions (Souza et al. 2010), similar to the Typic quartzipsaments. The $\mathrm{Mn}, \mathrm{Cu}$ and $\mathrm{Zn}$ contents are low, but the Fe content is very high, indicating the element concentration in the mottled form (Table I). The common, medium and fine roots in the A and E1 horizons, and rare in the E2 horizon, point impediment to root development with depth (Table I), and it may be related to the mottled, and the high concentration of Fe element.

The Typic Eutrustalf presents $\mathrm{pH}$ suitable for agricultural use in all horizons (Table IV), with average levels of $\mathrm{Ca} . \mathrm{Mg}, \mathrm{K}$, reflecting on medium SB and CEC, combined with the very low P content. Oliveira et al. (2009) studying semiarid soils observed values of $\mathrm{Ca}$ and $\mathrm{Mg}$ contents similar. Despite that even being classified as eutrophic, it presented low CEC, indicating low ability to provide nutrients for plants, denoting low soil fertility. Nevertheless, it presents higher fertility than the Typic quartzipsaments and Arenic Haplustulf, mainly in the A horizon. In this horizon, the $\mathrm{OC}$ content is high, resulting in tendency to present higher levels of CEC. Despite being found in small quantities in comparison with the mineral fraction, the $\mathrm{OM}$ is important for agricultural production systems due to the effects that produces in the chemical, physical and biological soil properties (Silva et al. 2006). There is no limitation to agricultural use by salinity. But, regarding to the micronutrients contents, the values are low, in all horizons, it is necessary to apply fertilizers, according to the culture recommendation.

Other researchers which studied and characterized different classes of semi-arid soils, such as Corrêa et al. (2009), Oliveira et al. (2009), Cunha et al. (2010), observed results that corroborate those found in this research. The OC contents in soils of semi-arid region are low, as a consequence of the climatic and physical conditions which it does not favor greater production and accumulation of organic material in the soil. Hence, the importance of adopting soil management practices that contribute to the organic matter increase of soils in this region. When Menezes and Silva (2008) were studying the effects of six years organic fertilization on the chemical characteristics of a Entisol Psamment cultivated with potatoes in the northeastern semi-arid region, they concluded that the annual application of manure, combined or not with the crotalaria, elevated the total levels of OC, $\mathrm{N}$ and $\mathrm{P}$, and $\mathrm{Zn}$ in the $0-20 \mathrm{~cm}$ layer of depth and the levels of extractable $\mathrm{P}$ and $\mathrm{K}$, and $\mathrm{Mg}$ and $\mathrm{B}$ in two evaluated layers. Despite the cultivation and the annual incorporation of crotalaria does not have a significant effect in the soil nutrient levels, the results suggest that the use of lower doses of manure, combined with the incorporation of green 
manures can ensure the maintenance of soil fertility in long term. Characterizing the distribution of $\mathrm{P}$ in different orders of semi-arid soils of Pernambuco and Paraíba states. Silveira et al. (2006) observed that the organic fraction represents up to $33 \%$ of the total fractions in soils as the Typic quartzipsaments, with low P contents. Giongo et al. (2011) suggest that the use of cover crops to increase the soil organic matter content, to reduce the evapotranspiration and consequently, the salinization process, it is essential to the agricultural systems sustainability in semi-arid regions.

\section{CONCLUSIONS}

The Eutric Haplustept presents vulnerability to physical and chemical degradation due to poor drainage, with risks of erosion, waterlogging, salinization and compaction, but it has good natural fertility. The Abrupt Kandiustalf presents high vulnerability to physical degradation due to strong presence of gravels and pebbles, which may also limit the development of deep-rooting plants and mechanization, but it has good natural fertility. The Typic quartzipsaments and the Typic Eutrustalf present no limitations related to drainage as well as low risk of compaction, but they have as limitation low moisture-holding capacity and natural fertility. The Arenic Haplustulf presents high vulnerability to degradation due to the drainage limitation related to the Btx horizon cementing, in addition the low natural fertility and it is not recommended its agricultural use. The amount of OM is low in all soils and the use of management systems that aim their accumulation and maintenance in appropriate levels will contribute to the increase in the CEC, as well as to improve their chemical and physical properties.

\section{ACKNOWLEDGMENTS}

We thank Conselho Nacional de Desenvolvimento Científico e Tecnológico (CNPq), CHESF and EMBRAPA for the financial support, to
Coordenação de Aperfeiçoamento de Pessoal de Nível Superior (CAPES) by the research grant.

\section{REFERENCES}

ALVAREZ VH, NOVAIS RF, BARROS NF, CANTARUTTI RB AND LOPES AL. 1999. Interpretação dos resultados das análises de solos. In: Ribeiro AC, Guimarães PTG and Alvarez VH (Eds), Recomendações para o uso de corretivos e fertilizantes em Minas Gerais: $5^{\text {a }}$ aproximação. Viçosa, CFSEMG, cap. 5, p. 25-32.

ARAÚJO MSB, SCHAEFER CEGR AND SAMPAIO EVB. 2004. Frações de fósforo após extrações sucessivas com resina e incubação, em Latossolos e Luvissolos do semiárido de Pernambuco. Rev Bras Cienc Solo 28: 259-268.

BRASIL. 1973. Ministério das Minas e Energia. Departamento Nacional de Produção Mineral. Parte das folhas SC.23 São Francisco e SC.24 Aracaju; geologia, geomorfologia, solos, vegetação e uso potencial da terra. Rio de Janeiro (Levantamento de recursos naturais, 1).

CASTRO SS AND HERNANI C. 2015. Solos frágeis: caracterização, manejo e sustentabilidade. Brasília, DF: Embrapa. 367 p.

CORREAA RM, FREIRE MBGS, FERREIRA RLC, FREIRE FJ, PESSOA LGM, MIRANDA MA AND MELO DVM. 2009. Atributos químicos de solos sob diferentes usos em perímetro irrigado no semiárido de Pernambuco. R Bras Cienc Solo 33: 305-314.

CUNHA EQ, STONE LF, MOREIRA JAA, FERREIRA EPB, DIDONET AD and LEANDRO WM. 2011. Sistemas de preparo do solo e culturas de cobertura na produção orgânica de feijão e milho. I Atributos físicos do solo. Rev Bras Cienc Solo 35: 589-602.

CUNHA TJF, PETRERE VG, SILVA DJ, MENDES AMS, MELO RF, OLIVEIRA NETO MB, SILVA MSL AND ALVAREZ IA. 2010. Principais solos do Semiárido tropical brasileiro: caracterização, potencialidades, limitações, fertilidade e manejo. In: SÁ IB, SILVA PCG, editores. Semiárido brasileiro: pesquisa, desenvolvimento e inovação. Petrolina: Embrapa Semiárido, p. 50-87.

CUNHA TJF, SILVA FHBB, SILVA MSL, PETRERE VG, SÁ IB, OLIVEIRA NETO MB AND CAVALCANTI AC. 2008. Solos do Submédio do Vale do São Francisco: potencialidades e limitações para uso agrícola. Petrolina: Embrapa Semiárido. (Documentos, 211).

DANTAS JA, SANTOS MC AND HECK RJ. 1998. Caracterização de Podzólicos Amarelos irrigados e não irrigados do Submédio São Francisco. Rev Bras Cienc Solo 22: 761-771.

DONAGEMA GK, CAMPOS DVB, CALDERANO SB, TEIXEIRA WG AND VIANA JHM. 2011. Manual de métodos de análise de solo. $2^{\mathrm{a}}$ ed., Rio de Janeiro: Embrapa Solos. Documentos, 132. 
FARIA CMB, SILVA MSL AND SILVA DJ. 2007. Alterações em Características de Solos do Submédio São Francisco Sob Diferentes Sistemas de Cultivo. Petrolina: Embrapa Semi-Árido. Boletim de Pesquisa e Desenvolvimento, 74.

FREIRE MBGS AND FREIRE FJ. 2007. Fertilidade do solo e seu manejo em solos afetados por sais. In: Novais RF, Alvarez VH, Barros NF, Fontes RLF, Cantarutti RB and Neves JCL (Eds), Fertilidade do solo. Viçosa, MG: Sociedade Brasileira de Ciência do Solo. cap. 16, p. 929954.

GENUCHTEN MT. 1980. A closed-form equation for predicting the conductivity of unsaturated soils. Soil Sci Soc Am J 44: 892-897.

GIONGO V, MENDES AMS, CUNHA TJF AND GALVÃO SRS. 2011. Decomposição e liberação de nutrientes de coquetéis vegetais para utilização no Semiárido brasileiro. Rev Ci Agron 42: 611-618.

JACOMINE PKT, CAVALCANTI AC, RIBEIRO MR, MONTENEGRO JO, BURGO N, MELO FILHO HFR AND FORMIGA RA. 1976. Levantamento exploratório: reconhecimento de solos da margem esquerda do rio São Francisco, Estado da Bahia. Recife: SUDENE - DRN, v. $1,404 \mathrm{p}$.

LEPSCH IF. 2011. 19 Lições de Pedologia. São Paulo: Oficina de Textos, $456 \mathrm{p}$.

MENEZES RSC AND SILVA TO. 2008. Mudanças na fertilidade de um Neossolo Regolítico após seis anos de adubação orgânica. Rev Bras Eng Agríc Ambiental 12: 251-257.

MILLENNIUM ECOSYSTEM ASSESSMENT. 2005 Ecosystems and Human Well-Being: Synthesis. London: Millennium Ecosystem Assessment Series, $2^{\text {nd }}$ ed., 160 p.

MOTA JCA, ASSIS JÚNIOR RN, AMARO FILHO J AND LIBARDI PL. 2008. Algumas propriedades físicas e hídricas de três solos na chapada do Apodi, RN, cultivados com melão. Rev Bras Ci Solo 32: 49-58.

OLIVEIRA CV, KER JC, FONTES LEF, CURI N AND PINHEIRO JC. 1988. Química e mineralogia de solos derivados de rochas do grupo bambuí no norte de Minas Gerais. Rev Bras Cienc Solo 22: 583-593.

OLIVEIRA JB. 2005. Pedologia aplicada. $2^{\text {a }}$ ed., Piracicaba: FEALQ, $574 \mathrm{p}$.

OLIVEIRA LB, FONTES MPF, RIBEIRO MRR AND KER JC. 2009. Morfologia e classificação de Luvissolos e Planossolos desenvolvidos de rochas metamórficas no semiárido do nordeste brasileiro. Rev Bras Cienc Solo 33: 1333-1345.

REICHERT JM, BERVALD CMP, RODRIGUES MF, KATO OR AND REINERT DJ. 2014. Mechanized land preparation in eastern Amazon in fire-free forest-based fallow systems as alternatives to slash-and-burn practices: Hydraulic and mechanical soil properties. Agric Ecosyst Environ 192: 47-60.
REICHERT JM, REINERT DJ AND BRAIDA JA. 2003. Qualidade dos solos e sustentabilidade de sistemas agrícolas. Rev Cienc Amb 27: 29-48.

REICHERT JM, RODRIGUES MF, BERVALD CMP AND KATO OR. 2016. Fire-free fallow management by mechanized chopping of biomass for sustainable agriculture in eastern Amazon: Effects on soil compactness, porosity, and water retention and availability. Land Degr Dev 27(5): 1403-1412.

REICHARDT K AND TIMM LC. 2004. Solo, planta e atmosfera: conceitos, processos e aplicações. Barueri: Manole, $478 \mathrm{p}$.

RESENDE M, CURI N, RESENDE SB AND CORRÊA GF. 2002. Pedologia: base para distinção de ambientes. $4^{\mathrm{a}}$ ed., Viçosa, MG: NEPUT, $338 \mathrm{p}$.

RIBEIRO MR, OLIVEIRA LB AND ARAÚJO FILHO JC. 2012. Caracterização morfológica do solo. In: Ker JC, Schaefer CEGR and Vidal-Torrado P (Eds), Pedologia: fundamentos. Viçosa, MG: Sociedade Brasileira de Ciência do Solo, p. 47-80.

SANTOS EEF AND RIBEIRO MR. 2000. Influência da irrigação e do cultivo nas propriedades de um Latossolo e um Argissolo da região do submédio São Francisco: atributos morfológicos e físicos. Rev Bras Cienc Solo 24: 875-884.

SANTOS JCB, SOUZA JÚNIOR VS, CORRÊA MM, RIBEIRO MR, ALMEIDA MC AND BORGES LEP. 2012. Caracterização de Neossolos Regolíticos da Região Semiárida do Estado de Pernambuco. R Bras Cienc Solo 36: 683-695.

SANTOS RD, LEMOS RC, SANTOS HG, KER JC AND ANJOS LHC. 2005. Manual de descrição e coleta de solo no campo. Viçosa, MG, Sociedade Brasileira de Ciência do Solo, $100 \mathrm{p}$.

SILVA EM AND AZEVEDO JA. 2002. Influência do período de centrifugação na curva de retenção de água em solos de Cerrado. Pesq Agropec Bras 37: 1487-1494.

SILVA LS, CAMARGO FAO AND CERETTA C. 2006. Composição da fase sólida orgânica do solo. In: Meurer EJ (Ed), Fundamentos de química do solo. Porto Alegre: Evangraf, Cap. 3, p. 63-90.

SILVA MSL, FERREIRA GB, MENDES MAS, GOMES TCA, OLIVEIRA NETO MB, SANTOS JCP AND CUNHA TJF. 2007. Coquetéis vegetais para manejo de solos em sistemas irrigados de cultivo orgânico de fruteiras no Submédio São Francisco, região Semi-Árida do Nordeste do Brasil. Rio de Janeiro: Embrapa Solos.

SILVEIRA MML, ARAÚJO MSB AND SAMPAIO EVSB. 2006. Distribuição de fósforo em diferentes ordens de solo do semi-árido da Paraíba e de Pernambuco. Rev Bras Ci Solo 30: 281-291.

SOIL SURVEY STAFF. 2014. Keys to Soil Taxonomy, $12^{\text {th }}$ ed., USDA-Natural Resources Conservation Service, Washington, DC. 
SOUZA RVCC, RIBEIRO MR, SOUZA JUNIOR VS, CORRÊA MM, ALMEIDA MC, CAMPOS MCC, RIBEIRO FILHO MR AND SCHULZE SBB. 2010. Caracterização de solos em uma topoclimossequência no maciço de Triunfo - sertão de Pernambuco. Rev Bras Ci Solo 34: 1259-1270.
STOLF R, THURLER AM, BACCHI OOS AND REICHARDT K. 2011. Method to estimate soil macroporosity and microporosity based on sand content and bulk density. R Bras Cienc Solo 35: 447-459.

VEZZANI FB. 2015. Solos e os serviços ecossistêmicos. Rev Bras Geog Fís 08: 673-684. 